\title{
Technical-Economic Analysis of Photovoltaik Reverse Osmosis Planning for Fulfillment of Fresh Water System on Ro-Pax Ship
}

\author{
Edi Jadmiko ${ }^{1}$, TonyBambang Musriyadi ${ }^{2}$, Amiadji $^{3}$, Dian Nafi Ahmad ${ }^{4}$
}

\begin{abstract}
- the need for fresh water in the world of industry is increasing with the rapid development of the global industry. The shipping industry is having a significant impact as part of a global industry concerning the sector of freshwater demand on ships. Freshwater supplies on ro-pax vessels are very important because they are the source of crew and passenger life when ships sail. Fulfillment of freshwater needs on a ro-pax vessel is made in a conventional system by filling clean water into a freshwater tank from the port. In this final project will be analyzed technical and economical on designing fresh water system using reverse osmosis system with solar panel as power supply and compare it with conventional system on ship MV. SABUK NUSANTARA 56. This Final Project includes installation design, size of fresh water tank, amount of cargo, investment cost and operational cost. The conclusion obtained in this final project is a reverse osmosis (RO) system with solar panels as a very efficient power supply when applied to ro-pax ships such as ships MV SABUK NUSANTARA 56 because with this system the ship is able to produce their own fresh water, the size of the freshwater tank is smaller, for new shiploads can be increased. For the percentage of total cost of fresh water needs is dearer about 52 percent compared to conventional system and payload value increased 29.2 percent compared to conventional system.
\end{abstract}

Keywords - fresh water, ro-pax, reverse osmosis, solar panel, technical, economical.

\section{INTRODUCTION}

$\mathrm{U}$ tilization $^{1}$ of technology impact strategies from the progress of global industry affect the availability of natural resources. Indonesia as a part of the world with a contribution of $3.5 \%$ of the world's population reaching 253,609,643 people with an area of $5,180,053 \mathrm{~km}^{2}$.This amount makes Indonesia as the fourth country with the largest population in the world according to data from the US Department of Commerce Census Bureau [1]. Approximately 1.2 billion people worldwide do not have access to adequate clean water [2].This phenomenon also affects the shipping industry in whose operations require fresh water. Technological advances, especially in the field of shipping, encourage the development of technology that is fast-paced, easy and efficient in designing a ship or in the use of a ship.Inside a ship there are various systems such as fresh water systems where the system governs the supply of fresh water for all the freshwater needs of the vessel. The freshwater system in this ship is a very vital system, This is because fresh water is used for eating, drinking, bathing, washing the crew and passengers, cooling the engine and other needs on board[6]. In general, the supply of clean water on a Ro-Pax vessel is carried out by

Edi Jadmiko, Department of Marine Engineering Institut Teknologi Sepuluh Nopember, Surabaya 60111, Indonesia, Email : gusjadmiko@gmail.com

Tony Bambang Musriyadi, Department of Marine Engineering Institut Teknologi Sepuluh Nopember, Surabaya 60111, Indonesia, Email : tonybambang8@gmail.com

Amiadji, Department ofMarine Engineering Institut Teknologi Sepuluh Nopember, Surabaya 60111, Indonesia, Email amiadji@gmail.com

Dian Nafi' Ahmad, Department ofMarine Engineering Institut Teknologi Sepuluh Nopember, Surabaya 60111, Indonesia, Email : diannafi.ahmad@gmail.com conventional means by filling clean water in a freshwater tank from the port as contained on the ship KM.SABUK NUSANTARA 56, but there are several vessels already equipped with a distillator used on Certain conditions.For long shipping routes requires a lot of clean water. This means that the size of the water tank becomes so large that the use of space on the ship becomes less efficient. Likewise, the cost of providing clean water also becomes larger. To save space in a vessel with a clean water tank size, clean water should not only be provided at the harbor, but clean water is also provided through seawater desalination technology to fresh water. In addition to other desalination technology distillation is Reverse Osmosis technology(RO)[7].

These studies show that PVRO systems are technically feasible [3]. The use of solar power by using solar panels as a source of energy of Reverse Osmosis technology is also an energy-saving strategy that is environmentally friendly and has an impact on the cost efficiency of water supply. This system is widely used in power generation industries such as steam power plants and is still rarely used in ships. With the change of design of fresh water system installation by using conventional system to design of fresh water system by addition of Reverse Osmosis (RO) system using solar power as power supply, it will also effect on the change of piping system and electricity. Changes to the changes will be reviewed further technically and economically [4].

\section{A. Research Methodology}

The methodology of the final task is a systematic sequence of stages of final project work done since the beginning of the work up to the end. The writing of this final project is research so that real data is needed to support the research implementation. The 
methodology used by the authors in conducting this research generally begins with the identification of the problem, the determination of the ship to be used as the object of research, literature study, data collection, design of freshwater system design with reverse osmosis solar panel system design planning, technical and economic analysis, With conventional systems, evaluation, analysis of discussion, and concluding conclusions and suggestions.

B. Problem Identification and Formulation

It is an early stage in conducting research so it is known what problem will be lifted. In writing this final assignment problem taken is fresh water system at research object that ship KM.SABUK NUSANTARA 56 which use reverse osmosis system then in power supply with solar panel with fokusan problem at efisensi and cost incurred to fulfill ship operational requirement.

C.Study of literature

At this stage is done learning of the theories that support the research and will be discussed in the writing of the final task. The theory is related to freshwater systems in ships, sea water systems, reverse osmosis, photovaltaic systems on ships. Resources used as a reference can come from books, journals, papers and the Internet.

D. Data collection

Data collection aims to obtain information related issues that will be discussed in the writing of this thesis so that field study is needed in the collection of data. The types of data to be collected at this stage include :

- Data GA MV. SABUK NUSANTARA 56

- Data layout fresh water system

- Dataspecification equipment fresh water system

E. Technical Analysis

At this stage will be discussed about technical analysis of freshwater systems using solar panels as a power supply reverse osmosis system and its operations, while to be analyzed is :

1. Layout

2. Components

3. Power needs and transmissions

4. Location

F. Economic Analysis

At this stage calculation of investment cost and operation of solar panel reverse osmosis system on freshwater system of ship MV.SABUK NUSANTARA 56. So that is known estimate installation cost on ship. The costs to be calculated are:

1. Equipment costs

2. Operating costs

3. Maintenance cost

G. Analysis and Discussion

To know the advantages and disadvantages of using solar panels as a reverse osmosis system power supply in freshwater systems MV.SABUK NUSANTARA 56.

H. Conclusions and Recommendations

After the process of analysis and discussion, then draw conclusions from the results of research. Conclusions based on the results of data analysis and discussion that has been done. Next is to provide suggestions provided as input and consideration material related parties to conduct further analysis.

\section{RESULT AND DISCUSSION}

A. Data Planning

In this final project discuss about system of fulfillment of freshwater requirement of ship by comparing two system that is using reverse osmosis system with conventional system of supply from port. In comparing the two systems using the object of research ship KM.SABUK NUSANTARA 56 belongs to the Ministry of Transportation Directorate General of Sea Transportation built at PT. Adiluhung Saranasegara Indonesia with main dimensions as follows:

\begin{tabular}{lll}
$\begin{array}{l}\text { Name of Ship } \\
\text { Owner }\end{array}$ & :KM.SABUK NUSANTARA 56 \\
Direktorat JendralPerhubungan \\
$\begin{array}{l}\text { Laut } \\
\text { Type of Ship }\end{array}$ & :Ro-pax \\
Shipyard & :PT. Adiluhung Saranasegara \\
\multicolumn{4}{l}{ Indonesia } \\
Leght O.A & $: 58.50$ & $\mathrm{~m}$ \\
Leght B.P & $: 52.30$ & $\mathrm{~m}$ \\
Beam Mld & $: 12.00$ & $\mathrm{~m}$ \\
Depth Mld & $: 4.50$ & $\mathrm{~m}$ \\
Draft & $: 2.90$ & $\mathrm{~m}$ \\
Vs & $: 12$ & $\mathrm{knot}$ \\
Main Engine & $: 2 \times 829$ & HP \\
Crew & $: 21$ & Person \\
Max.Pass & $: 285$ & Person
\end{tabular}

B. Calculation of Freshwater Needs

On the ship MV.SABUK NUSANTARA 56 is using the main engine amounted to 2 sets with the same specifications. The main engine specifications are as follows:

$\begin{array}{ll}\text { Name of Product } & \text { : YANMAR } \\ \text { Type } & : \text { 6AYM-ETE M } \\ \text { Max Power } & : 610 \mathrm{~kW}(829 \mathrm{HP}) \\ \text { Number of Cylinder } & : 6 \text { in-line } \\ \text { Bore } x \text { Stroke }(\mathrm{mm}) & : 155 \times 180 \\ \text { Rpm } & : 1900 \\ \text { SFOC } & : 150 \mathrm{~g} / \mathrm{kWH}\end{array}$

From the main engine data will be calculated the distance of the vessel ship KM.SABUK NUSANTARA 56 with the following calculation formula:

$$
\begin{aligned}
& \mathrm{VFO}=\frac{\mathrm{WFO}}{\gamma \mathrm{FO}} \\
& 150 \mathrm{~m}^{3}=\frac{\text { WFO }}{0.89 \text { ton } / \mathrm{m}^{3}} \\
& \mathrm{~W} F O=133,5 \\
& \mathrm{WFO}=\text { BHP } \times \text { SFOC } \times \frac{\mathrm{S}}{V \text { service }} \times 1,3 \times 10^{-6} \\
& 133,5=(2 \times 829) \times(2 \times 150) \times \frac{S}{12} \times 1,3 \times 10^{-6} \\
& \mathrm{~S}=2477,49 \text { sea miles } \\
& \text { Time of Radius : } \\
& \mathrm{S} \quad=\mathrm{V} \times \mathrm{T} \\
& \mathrm{T}=\frac{2477,49}{12 \mathrm{knot} / \mathrm{mil}} \\
& \mathrm{T} \quad=206,46 \mathrm{jam}=8,6 \text { hari }
\end{aligned}
$$


So the ship MV.SABUK NUSANTARA 56 is operating for approximately 9 days.

It is known that fresh water tank capacity from ship data MV. SABUK NUSANTARA 56 is $140 \mathrm{~m}^{3}$ then it is equal to 140.000 liters. The operation of the ship MV.SABUK NUSANTARA 56 approximately 9 days, then in one day the operation of the ship requires 15,556 liters of fresh water per day.
C. Design of Fresh Water SystemsMV. SABUK NUSANTARA 56

In general, the supply of clean water is done at the port by means of filling clean water in fresh water tanks. From fresh water tank (FW Tank) clean water is distributed to each deck by using pressure tank (hydrophore) equipped with fresh water pump (FW Pump).

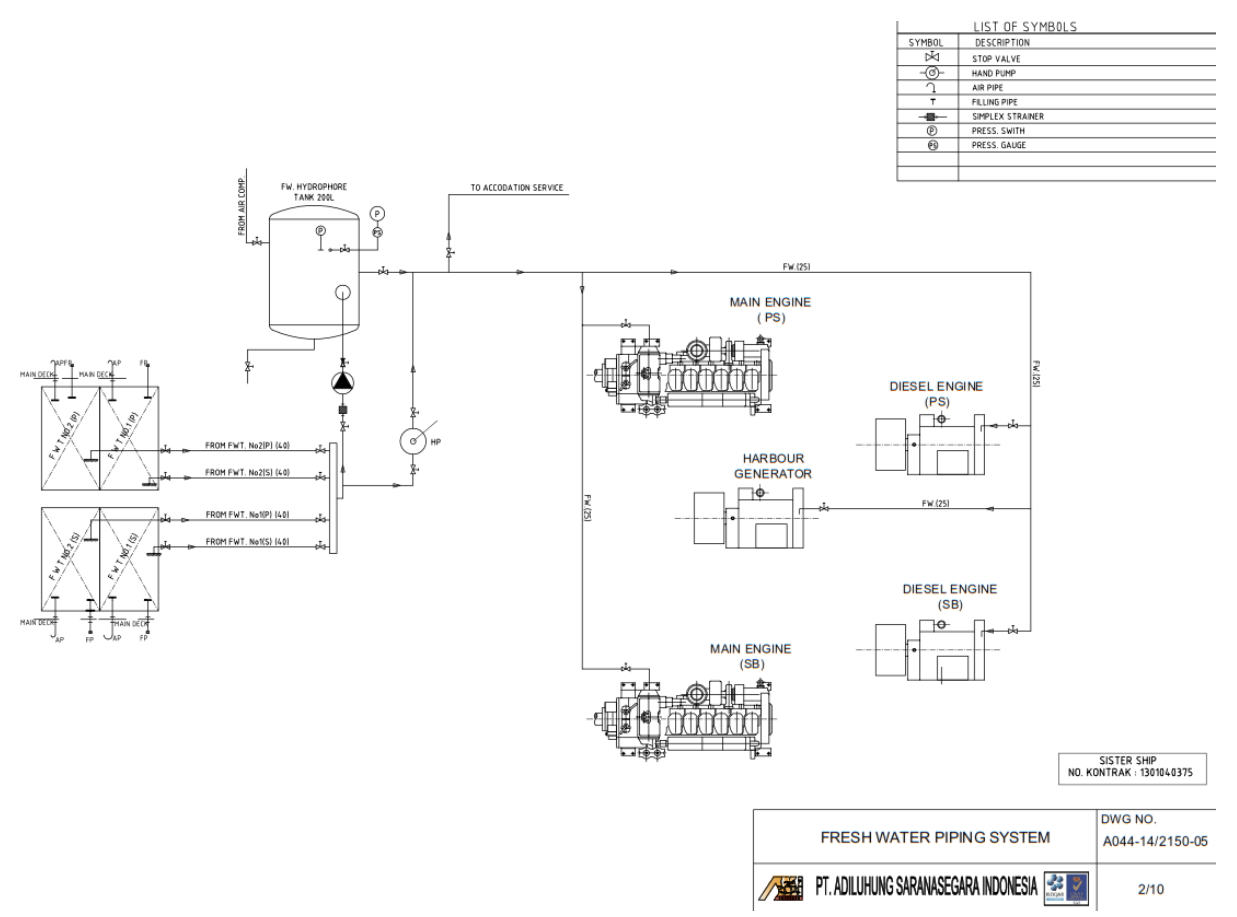

Figure. 1.Freshwater systems conventionally on shipsMV. SABUK NUSANTARA 56

In figure 1 layout design of freshwater ship system MV.SABUK NUSANTARA 56 where in the picture seen flow of distribution of fresh water in supply from the port which will be distributed in places that need through hydropore.

E. Design of Fresh Water System With Reverse Osmosis SystemMV. SABUK NUSANTARA 56

Freshwater system with Reverse Osmosis system is a fresh water system that has been equipped with a desalination system to convert salt water into fresh water. On the ship MV.SABUK NUSANTARA 56 the planned desalination system is using Reverse Osmosis technology. The workings of this system is to move water through one stage to the next stage ie the more dilute to the more concentrated. This system is capable of filtering $99 \%$ of bacteria and particles with a diameter of $0.0001 \mu \mathrm{m}$, resulting in good fresh water worth consumption.

To design a Reverse Osmosis system required three stages, among others, as follows:

$>$ Raw water quality analysis.

$>$ Selection of component specifications used. The selection of equipment specifications is based on raw water quality and required capacity.

$>$ Reverse Osmosis system design and plan.

The design or plan of the water treatment unit is presented into the design drawing to facilitate the workmanship[8].

F.Raw Water Quality Analysis
The raw water quality index is based on sea water content parameters, from laboratory data of sanitation techniques, the following data are generated :

$>$ TDS $35.000 \mathrm{ppm}$ at temperature $25^{\circ} \mathrm{C}$

$>$ TDS $42.000 \mathrm{ppm}$ at temperature $30^{\circ} \mathrm{C}$

$>\mathrm{NaCl}$ of $20 \mathrm{gr} / \mathrm{l}$

$>$ Salt density $1,5 \mathrm{gr} / \mathrm{l}$

The data as a reference in determining the required osmotic pressure. Calculation of osmotic pressure as follows :

Volume of $\mathrm{NaCl}=\frac{20 \mathrm{gr}}{1,5 \mathrm{gr} / \mathrm{ml}}=13,3 \mathrm{ml}$ (4)

Volume of solvent $\quad=1000 \mathrm{ml}-13,3 \mathrm{ml}=0,99867 \mathrm{l}$

Osmotic pressure $(\pi)=1,12(\mathrm{t}+273) \Sigma \mathrm{mi}(5)$

$=1,12(25+273)\{20 \mathrm{gr}:[(23+35,5) / 0,9987]\}$

$=113,95$ Psi $(7,97$ bar $)$

The above calculation shows the magnitude of osmotic pressure for salt water (raw water) containing $20 \mathrm{~g}$ of $\mathrm{NaCl}$ is $113,95 \mathrm{Psi}$, so that required pressure greater than 113,95 Psi to be able to filter salt molecule by membrane.

G.Selection of Component SpecificationsRO

The components of Reverse Osmosis system that will be used on board KM.SABUK NUSANTARA 56 consists of 3 main components, among others:

$>$ Early level processing unit

$>$ Reverse Osmosis unit

$>$ Power supply unit

Initial processing units are used to treat seawater before being processed in a Reverse Osmosis unit. 
Seawater close to the coast still contains suspended solid particles, plankton minerals and others, then the raw water needs to be done preliminary processing. The preliminary processing unit that will be used on the ship Reverse Osmosis system MV.SABUK NUSANTARA 56 consists of several main equipment among others :

1. Clarifier Pumps

Clarifier pumps are used to pump seawater into raw water tanks. This pump is planned to use seawater pump which already exist in ship MV.SABUK NUNTARA 56. Specification of pump clarifier are:

Pump Type : Centrifugal Pump (Self Priming)

Capacity $: 3 \mathrm{~m} 3 / \mathrm{h}$

Pressure : $: 1.6 \mathrm{MPa}$

2. Raw Water Tank

Raw water storage tanks serve to accommodate sea water to be processed with Reverse Osmosis system. The tank to be used is pressuretank / hydrophore (SW pressuretank/hydrophore) tank which has been installed on the ship MV.SABUK NUSANTARA 56. Specification of raw water tank are:

$\begin{array}{ll}\text { Type } & : \text { Seawater pressure tank } \\ \text { Capacity } & : 3 \mathrm{~m} 3 / \mathrm{h}\end{array}$

Pressure $\quad: 1.6 \mathrm{MPa}$

3. Dosing KMnO4 Pumps

It functions to inject a solution of Potassium Permanganate (KMnO4) to oxidize iron or manganese present in raw water. The dosing pump specifications are:

Model / Type : Chemtech series 100 / X003

$\begin{array}{ll}\text { Pressure } & : 7 \text { bar } \\ \text { Capacity } & : 4.72 \mathrm{LPH} \\ \text { Pump Head } & : \text { PVC } \\ \text { Diaphragm } & : \text { Hypalon } \\ \text { Number } & : 3 \text { units }\end{array}$

4. KMnO4 Tank

Serves to accommodate potassium permanganate solution (KMnO4). This solution serves as an oxidizing agent to decrease the content of organic matter and soda ash which is used to raise the $\mathrm{pH}$ towards neutral. The use of potassium permanganate is intended to kill pathogenic bacteria, so it does not cause any problems in the subsequent filtration system due to biological processes (formation of crust, moss etc.). The $\mathrm{KmnO} 4$ tank specifications are:

$\begin{array}{ll}\text { Model } & \text { : BT } 5040 \\ \text { Volume } & \text { : } 50 \text { liters } \\ \text { Dimensions } & \text { : Ø } 50 \mathrm{~cm} \mathrm{x} 40 \mathrm{~cm} \\ \text { Material } & \text { : FRP } \\ \text { Number } & \text { : } 3 \text { units } \\ \text { 5. Reactor Tank }\end{array}$

Serves to accommodate the process of mixing between raw water and certain chemicals. Usually used potassium permanganate or chlorine that serves as an oxidizing agent to decrease the content of organic matter and soda ash used to raise the $\mathrm{pH}$ towards neutral. The reactor tank specifications are:

$\begin{array}{ll}\text { Capacity } & : 0.5-1 \mathrm{~m} 3 / \text { hour } \\ \text { Dimensions } & : 63 \mathrm{~cm} \times 120 \mathrm{~cm} \\ \text { Material } & : \text { FRP } \\ \text { Pressure } & : 4 \text { bar } \\ \text { Number } & : 1 \text { unit }\end{array}$

\section{Prefilter}

The 5 micron filter is used as a filter to remove almost any small particles suspended from raw water. It is recommended that the filter cartridge be replaced regularly, depending on the quality of the raw water. The prefilter specification is a package with a Reverse Osmosis unit.

\section{Active Carbon Filter}

All Eliminator models are equipped with automatic backwash activated carbon filter (ACF) designed to remove oxidizers such as chlorine or chloramines, manganese and other organic impurities from raw water. Active carbon filter specification is a package with Reverse Osmosis unit.

8. High Pressure Booster Pump

This pump serves to pump raw water from the raw water tank to the Reverse Osmosis unit. This pump is a high pressure pump so it can push raw water through a reverse osmosis membrane that has a very small porosity. From the calculation of raw water quality analysis, the osmosis pressure for salt water (raw water) containing $20 \mathrm{~g}$ of $\mathrm{NaCl}$ is 113,95 Psi (7.97 bar), so that pressure is greater than 113,95 Psi (7.97 bar ) To be able to filter salt molecules by the membrane. The specification of the selected water pump is as follows:

$\begin{array}{ll}\text { Type } & : \text { One package with RO unit } \\ \text { Power } & : 3 \mathrm{HP}(2.24 \mathrm{KW}) \\ \text { Pressure } & : 180 \mathrm{Psi}(12.41 \mathrm{bar})\end{array}$

The reverse osmosis unit as the most important component of the overall water treatment system consists of a spiral-coated membrane membrane with a high-pressure resistant (vessel) protector. Specification of reverse osmosis unit selected as follows:

$\begin{array}{ll}\text { Brand } & : \text { Crane Environmental } \\ \text { Type } & : \text { Eliminator-VI } \\ \text { Capacity } & : 360 \mathrm{GPH} / 1363 \mathrm{LPH} \text { (32712 LPD) } \\ \text { Raw water } & :<1000 \mathrm{ppm} \\ \text { AR membrane } & : 99 \% \\ \text { Power Supply: } & 380 \mathrm{~V} / 220 \mathrm{~V}, 50 \mathrm{~Hz} / 60 \mathrm{~Hz}, 1 \mathrm{ph} / 3 \mathrm{ph} \\ \text { Pump / Motor } & : 3 \mathrm{HP}(2.24 \mathrm{KW}) \\ \text { Operating pressure: } 180 \text { Psi }(12.41 \mathrm{bar}) \\ \text { Dimensions (LxWxH): } 1168.4 \text { x } 812.8 \times 1651(\mathrm{~mm}) \\ \text { Weight } \quad: 363 \mathrm{~kg}\end{array}$

To accommodate the processed water from the RO unit before being distributed through the charging faucet. The tank of the product to be used is fresh water tank located on the right side (starboard) and left (portside) main deck ship. Both these tanks are a freshwater tank on a conventional system that has been scaled down. To maintain the stability of the ship, both tanks are designed with the same size and volume. Calculation of water tank product size as follows:

The need for fresh water during sailing $=140,000$ liters

Vessel operating time $=9$ days

Volume water tank product $=$ Water volume

Required in one day of voyage

$$
\begin{gathered}
=\frac{V \text { water during sailing }}{\text { Ship operating time }} \\
=\frac{140.000 \text { liter }}{9 \text { days }}
\end{gathered}
$$


International Journal of Marine Engineering Innovation and Research, Vol. 1(4), Sept. 2017. 330-345 (pISSN: 2541-5972, eISSN:2548-1479)

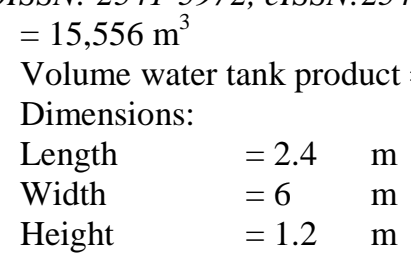

Volume $\quad=17.3 \mathrm{~m}^{2}$

Determination of the location of this product tank based on the location of conventional water tank general arrangement MV.SABUK NUSANTARA 56 which is in frame $22-41$ is planned to frame $39-41$, for the remaining space used as a void tank.

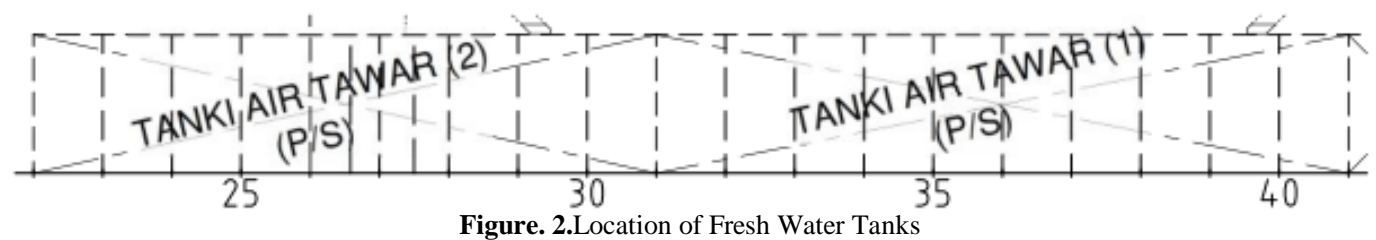

Figure of freshwater tanks are visible from the right side located on frames $22-41$ with the length of each frame spacing $600 \mathrm{~mm}$.

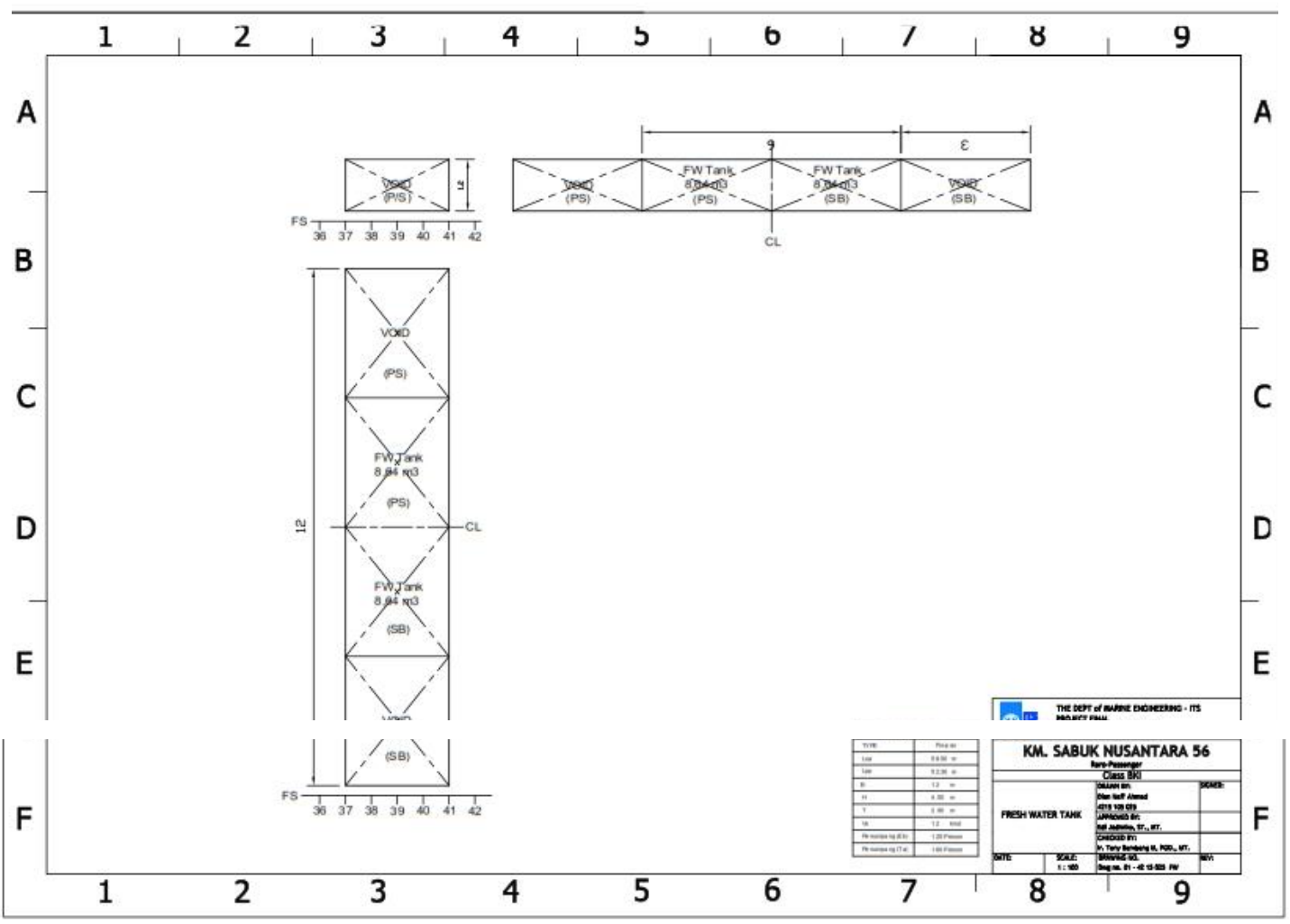

Figure. 3. Location of Water Tank Products 
The figure of the product water tank after being processed through the reverse osmosis system is seen from side view, front and top.

To pump processed water in the process of filling into places that require menggugunakan fresh water pump (fresh water pump) that already exist in the ship
MV. SABUK NUSANTARA 56. Specifications of water pump products are :
Pump Type : Centrifugal Pump
Capacity : : $3 \mathrm{~m} 3 / \mathrm{h}$
Pressure $\quad: 1.6 \mathrm{MPa}$

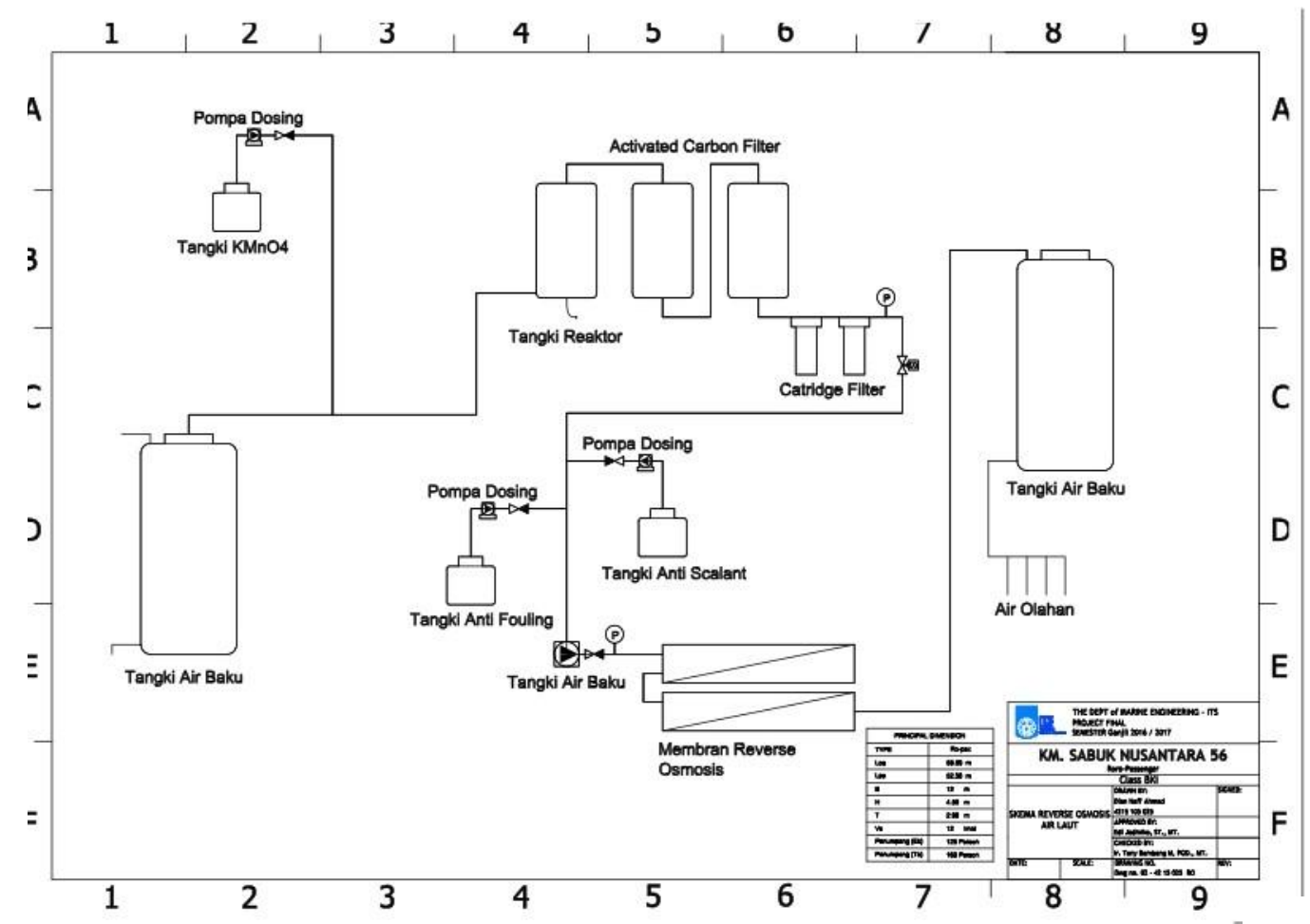

Figure. 4. Reverse Osmosis System Planning Scheme On Ship MV.SABUK NUSANTARA 56

The schematic drawing shows the plot of reverse osmosis system planning for in-product water products that are ready to be distributed to places that require it.

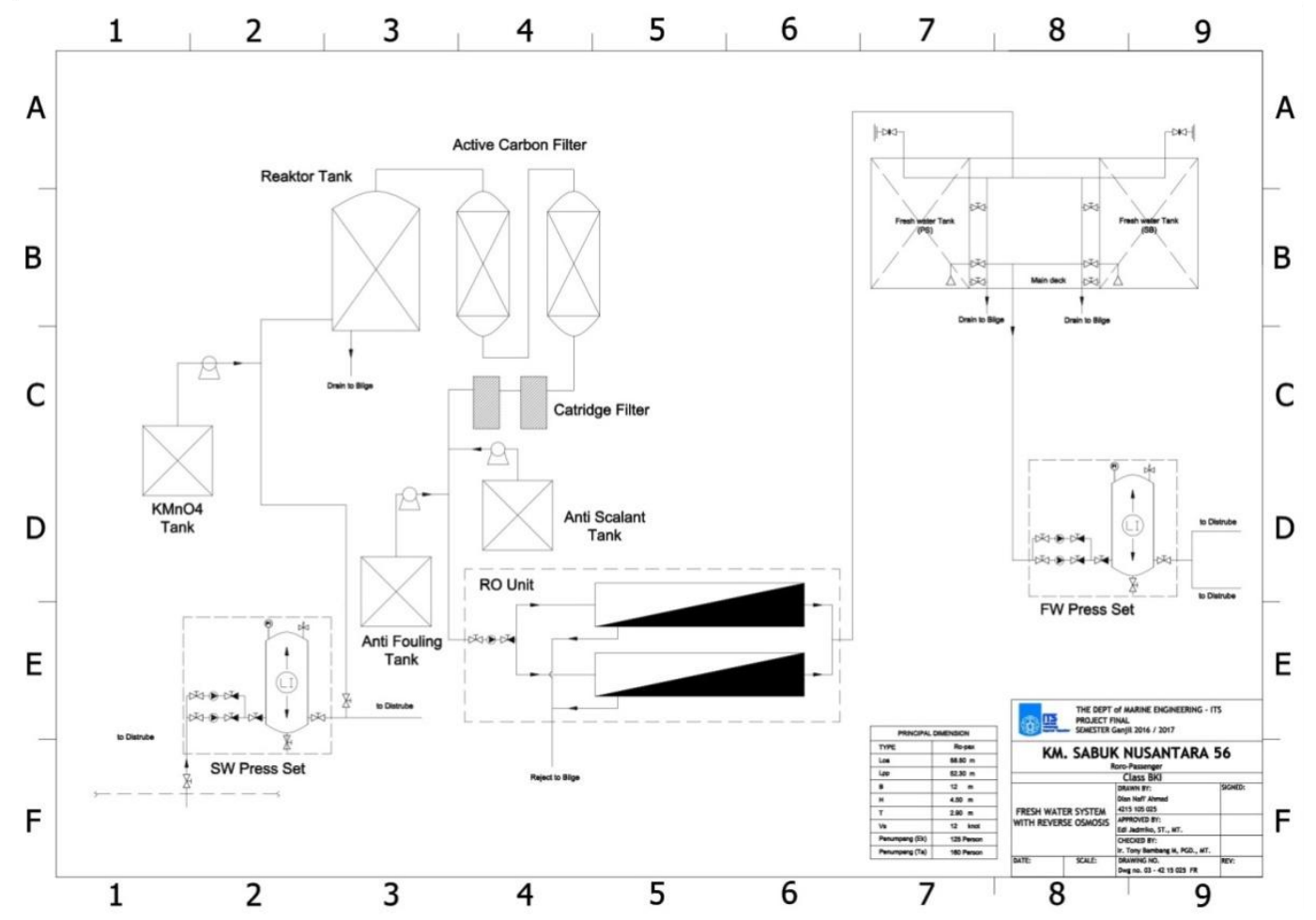

Figure. 5. Freshwater System Layout With Reverse Osmosis 
Raw water from sea water is pumped by using a clarifier/sea water pump pump to a raw water storage tank/S.W pressure tank (R2). From the raw water container tank, the raw water is pumped into the reactor tank (T2) while injected with potassium permanganate (KMn04) solution provided on KMn04 tank (T1) by using dosing pumps, so that the iron or manganese dissolved in raw water can be oxidized into A form of an iron or Manganese oxide compound that is insoluble in water. In addition, the application of potassium permanganate is an oxidizing agent which can also serve to kill microorganisms that can cause biofouling in the Reverse Osmosis membrane. From the reactor tank, the oxidized water and also the suspended solids (SS) in the form of fine particles, plankton and other oxidation products including iron and manganese are filtered by sand filter (F1). The water coming out of the sand filter is then fed to the Manganese Zeolite filter (manganese greensand filter) (F2). In the presence of these Zeolite Manganese filters, unreacted iron or manganese in the reactor tank may be removed until the concentration $<0.1 \mathrm{mg} / 1$. These iron and manganese must be removed first because they can cause scale in the membrane RO. From the Zeolite Manganese filter, water is passed to an activated carbon filter (F3) to remove odor or color and micro-pollutants. This filter has a function to remove color compounds in raw water which can accelerate the blockage of the adsorption oxygen membrane. After passing through the color-busting filter, water is passed to a cartridge filter (F4) which can filter particles of dirt to a size of 0.5 microns.From the cartridge filter, then water is flowed to the RO membrane unit (R3) by using a high pressure pump while injected with anti-crust (Anti-scalant) (T4) and anti-biofouling agent (T5). In this membrane RO unit occurs the process of filtering microorganisms, heavy metals, bacteria, viruses, inorganic materials and other hazardous materials dissolved in water. Thus only water molecules can penetrate the membrane so as to produce very pure water. Water coming out of the reverse Osmosis module is freshwater and concentrated salt water.

Furthermore, fresh water product is supplied by water tank product (Aft. Fresh watertank) which is located on the right side (starboard) and left side (portside) main deck ship.Sedangkan airbuangan or reject brine thrown mealui sistembilga.Dari water tank container water product tawardialirkan FW pressure tank / hydrophored by using FW pump. From FW pressuretank fresh water then distributed to each deck to meet all the freshwater needs on the vessel.

H. Selection of Power Supply Unit Specification

Power supply unit to run all Reverse Osmosis units that will be used on board MV.SABUK NUSANTARA consists of 2 kinds of components that are mutually sustainable, among others:

$>$ Unit solar panel

$>$ Battery pack

The number of batteries is greatly influenced by the power consumption required by the reverse osmosis unit to convert sea water into fresh water every day. This is related to the size of the desired device capacity and battery operational time. The details of power consumption required reverse osmosis system can be viewed from table 1 as follows:

TABLE 1 .

BREAKDOWN OF POWER CONSUMPTION OF REVERSE OSMOSIS SYSTEM

\begin{tabular}{|c|c|c|}
\hline Components & Units & Power \\
\hline Clarifier pump *) & 2 (SW pump) & $0 \quad \mathrm{~kW}$ \\
\hline $\mathrm{KmnO}_{4}$ dosing pump & 1 & $0,03 \mathrm{~kW}$ \\
\hline Antiscalant dosing pump & 1 & $0.03 \mathrm{~kW}$ \\
\hline Antifouling dosing pump & 1 & $0.03 \mathrm{~kW}$ \\
\hline Unit RO : High pressure pump & 1 & $2,24 \mathrm{~kW}$ \\
\hline Water pump products *) & 2 (FW pump) & $\mathrm{kW}$ \\
\hline Total power & & $2,33 \mathrm{~kW}$ \\
\hline
\end{tabular}

Clarifier pumps and water pump products using sea water and fresh water pumps on MV.SABUK NUSANTARA 56 ships that supply power from main ship generator. The battery functions as a storage of electrical energy generated from solar panels as a power supply in the reverse osmosis system. The battery selection is based on the required total power requirements per day (Wh), battery voltage $(\mathrm{V})$, and Deep of Discharge (DOD) battery $80 \%$. Determination of battery capacity to determine the specification first calculate the total $\mathrm{AH}$ as follows:
Battery capacity $=\mathrm{AH}$ total $=\mathrm{P}$ total equipment $/ \mathrm{V}$ battery $=(23300) / 12$ Volt $=1942 \mathrm{AH}$

Selected voltage 12 Volt because the total energy used per day is large enough, then used voltage $12 \mathrm{Vol}$ for the smaller current and losses can be minimized. Battery used is a battery in, so have DOD of $80 \%$ or 0.8 so the capacity of the battery used for:

$\mathrm{CB}=\mathrm{AHxd} / \mathrm{DOD}=1942 \times 1 / 0.8=2427.5$

The battery is only used $50 \%$ to meet the needs of electricity because the battery is often used more than $40 \%-50 \%$ will reduce lifetime. So used the size of 500 AH 12 V for 10 units. 
(pISSN: 2541-5972, eISSN:2548-1479)

Therefore the battery is selected with the following specifications:

$\begin{array}{ll}\text { Brand } & : \text { Enerdrive } \\ \text { Type } & : \text { Lithium - Ion } \\ \text { Voltage } & : 12 \text { Volt } \\ \text { Capacity of AH } & : 500 \mathrm{AH} \\ \text { Dimensions (LxWxH) } & : 623 \times 350 \times 374(\mathrm{~mm}) \\ \text { Weight } & : 75 \mathrm{~kg}\end{array}$

The battery required a total of 10 units of batteries with a parallel arrangement. The battery is placed on the inner bottom close to the reverse osmosis unit for easy installation and maintenance.

By designing the load to be used, we can determine the specifications of the solar panels used. The capacity of solar panels can be determined using the following equation:

Panel Capacity $=($ Total Energy / Solar Insulation $) \mathrm{x}$ Energy Band Gap $=(23300 / 10) \times 1.1=2563$

Taking into account system losses of $15 \%$, the large capacity of solar panels required with consideration of system losses are as follows:

Capacity of solar panel $=\mathrm{P}$ solar panel $+(15 \% \times \mathrm{P}$ solar panel $)=2563 \mathrm{~W}+(15 \% \times 2563 \mathrm{~W})$

$=2947.45 \mathrm{~W}=3000 \mathrm{~W}$

From the above calculation we can determine that the solar panel to be used has a 3000 WP panel specification, because the market does not have a specification value of $3000 \mathrm{WP}$, then used solar panels with 275 WP specifications as many as 11 pieces.

$\begin{array}{ll}\text { Brand } & : \text { Enhance Photovoltaics } \\ \text { Type } & : \text { XP-275 } \\ \text { Nominal Power } & : 275 \text { Watt } \\ \text { Short Circuit Current } & : 9.23 \text { Ampere } \\ \text { Dimensions (LxWxH) } & : 1640 \times 992 \times 40(\mathrm{~mm}) \\ \text { Weight } & : 18.5 \mathrm{~kg} \\ \text { Number } & : 11 \text { Units }\end{array}$

Solar panels are placed on top decks on frames 37 to 43 with $360^{\circ}$ angles facing the sky. On the shipping in Indonesia the average effectiveness of sunlight time is 10 hours ie at 07.00 to 17.00 . This is the reference of the Reverse Osmosis system, which is 10 hours per day, then the 23300 watt power required per day will be supplied with solar panels of 11 units with each unit producing 2750 watts every 10 hours.

Solar Charge Control controls overcharging due to the voltage of the solar panel The excess voltage and charging will reduce battery life The determination of solar charge control can be done by calculating the capacity of solar charge control in advance with the following formula [5]:

$\operatorname{Imax}=(\mathrm{P}$ solar panel $/ \mathrm{Vs})$

Imax $=3025 /$ x $12 \mathrm{~V}=252$ Ampere

Information:

Imax = Capacity Current solar charge control (A)

Ppanelsurya $=$ Total power of solar panel $($ Watt $)$

Vs = Battery Voltage (Volt)

Based on the calculation of total solar charge control capacity required then solar charge control better value yamg greater than the calculation and adjusted with the existing stock market. Then obtained solar charge control 100 Ampere as much as 3 units arranged parallel, the following specifications:

$\begin{array}{ll}\text { Brand } & \text { : Blue Solar Charge Control } \\ \text { Type } & \text { : MPPT 150/100 } \\ \text { Rated Charge Current } & : \text { 100 Ampere }\end{array}$

The inverter is used to convert the direct current (DC) of the battery into an alternating electrical current (AC) used to operate the reverse osmosis unit. The selected inverter must be at least capable of 3025 Watt input and should be able to provide 2330 Watt ouput. Based on these aspects then the inverter is selected with the following specifications:

$\begin{array}{ll}\text { Brand } & \text { : BlueSolar Grid Inverter } \\ \text { Type } & : 2800 \\ \text { Nominal output (AC) } & : 2800 \text { Watt } \\ \text { Maximum input (DC) } & : 3160 \text { Watt } \\ \text { Dimensions (LxWxH) } & : 376 \text { x } 415 \text { x } 125(\mathrm{~mm}) \\ \text { Weight } & : 14.8 \mathrm{~kg}\end{array}$

MCB (Miniature Circuit Breaker) is used as a safety carrier and other electrical equipment at low voltage. Based on the nominal current output of an inverter of 12 Ampere, it is possible to choose DPYC conductor type with a size of $2.5 \mathrm{~mm} 2$ that can flow a current of 20 Ampere with a rating of 20 Ampere MCB. 


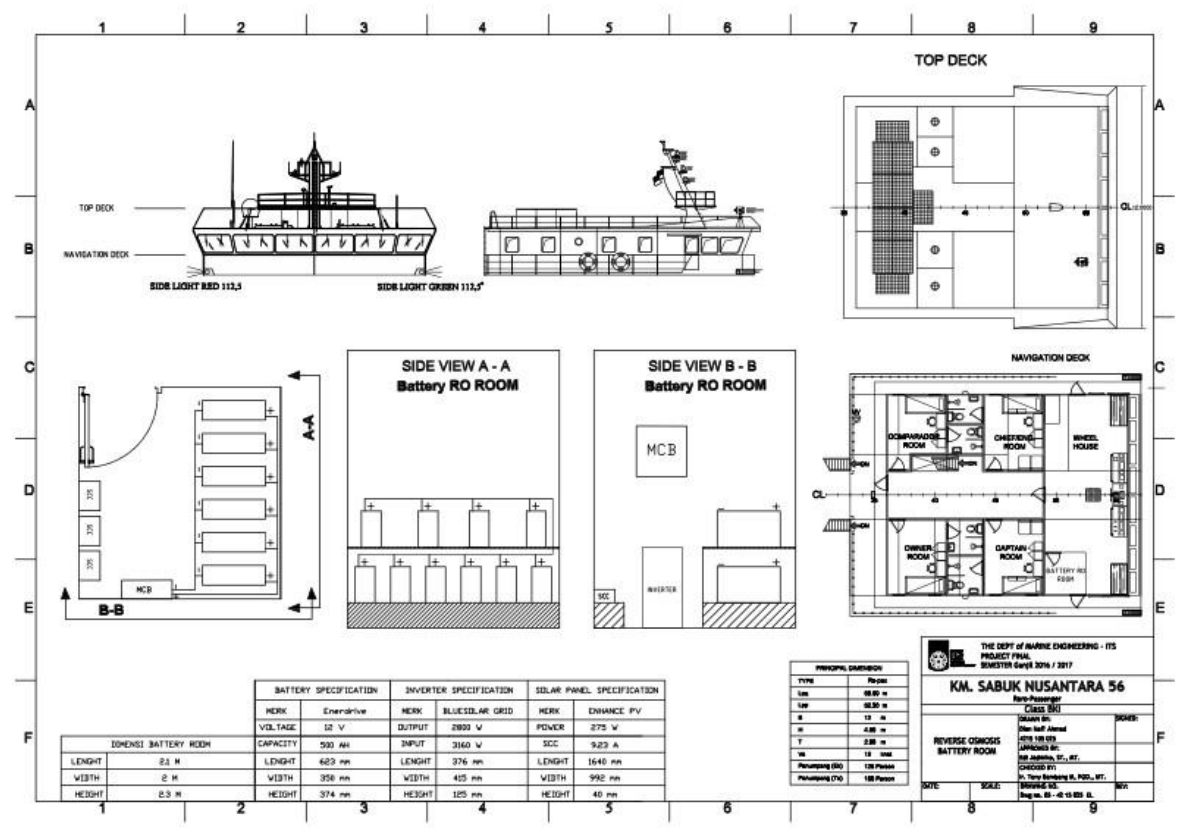

Figure. 6. Power Supply System Layout

The reverse osmosis power supply unit consists of solar panels as the earliest component in generating electricity from the heat of sunlight. The solar panel is placed on the top deck of frame 37 up to frame 43 by facing vertically to the sky with a 360 degree angle. Solar Charge Control regulates electricity from solar panels so they are not overcharged. Batteries as electrical storage components of solar panels that later become the power supply of reverse osmosis system. Inverter is needed to convert electric current direction (DC) from battery into electric current back and forth (AC) that is adjusted to need reverse osmosis system. MCB functioned as a safety of power supply unit. Components of these components, Solar Charge Control, batteries, inverters and mcb are placed in Battery RO Room in navigation decks on frames 49 to 53.

I. Technical Analysis of Reverse Osmosis System Changes in freshwater systems KM.SABUK NUSANTARA 56 from conventional systems into systems using reverse osmosis and solar panels have some technical consequences that are an integral part of the research. Some of the consequences include aspects of components, installation, location and operasinal.

1. Complex Installation System

In practice, freshwater processing with reverse osmosis system consists of two parts: the preliminary processing unit and the reverse osmosis unit. To support the operation of this system also requires many additional components such as chemical fluid tanks, filters, power supply controls, cables so that the piping installation system and electricity become more complex and long. The preliminary processing unit consists of several main equipment ie raw water pump, reactor tank, sand filter, zeolite manganese filter and color removal filter and $0.5 \mu \mathrm{m}$ catridge filter and dosing pump for anti scalant and anti biofouling. While the reverse osmosis unit consists of a high pressure pump and a semipermeable membrane. The reverse osmosis system power supply consists of starting solar panels, solar charge control, batteries, inverters and mcb as electrical conductor.

2. Minimize the size of fresh water tanks

From the data in the volume of freshwater tank system conventional MV.SABUK NUSANTARA 56 is $140 \mathrm{~m}^{3}$. The tank is divided into two sections located on the right side (starboard) and the left side (portside) bottom deck of each ship sounds $70 \mathrm{~m}^{3}$ volume. The location of the tank is at frame 22 to frame 41.

Size of freshwater tank with reverse osmosis system obtained from the data as follows:

- Need for fresh water during sailing 140,000 liters.

- Ship operating time $=9$ days

Volume (water tank product) $=$ Volume of water required in one day of voyage. The volume of water during sailing is divided by ship's operating time. 140,000 liters divided by 9 days equals 15,556 liters $\left(15.56 \mathrm{~m}^{3}\right)$. The location of a freshwater tank with a reverse osmosis system is the same as that of a conventional freshwater tank with reduced volume where the tank is located in frames 22 to 41 frames to only frame 39 to frame 41 with $600 \mathrm{~mm}$ spacing frame length.

From the calculations it can be compared that the size of freshwater tanks from conventional systems with reverse osmosis system retransmission has a tank size eight times smaller than conventional system tank sizes.

3. New Shipbuilding Enlarge Payload

Before calculating the amount of payload the value of DWT, LWT and displacement must be known. The relationship between DWT, LWT and displacement is seen in the following formulation:

DWT $=\Delta-$ LWT or $\Delta=$ DWT + LWT

Where: DWT $=$ Dead weight of ship

$\Delta=$ Displacement ship 
LWT $=$ Weight of ship components that are fixed

LWT components include the following:

- Heavy steel liner (WST)

- Outfit weight and accommodation (woa)

- Heavy machinery installation

- Weight reserves (wres)

From the data obtained in the DWT value is known as follows:

- Fuel

- Lubricating oil

- Fresh Water

- Passenger + luggage

- Crew + luggage

$$
\begin{aligned}
& : \pm 140 \text { Ton } \\
& : \pm 1 \text { Ton } \\
& : \pm 140 \text { Ton } \\
& : \pm 40 \text { Ton } \\
& : \pm 3 \text { Ton }
\end{aligned}
$$

$$
\begin{aligned}
& \text { - Provision } \\
& \text { - Cargo }
\end{aligned}
$$

Total DWT

$: \pm 6$ Ton \pm 420 Ton \pm 750 Ton

The payload of ships in a conventional fresh water system is 420 tons. Freshwater weight on a conventional system of 140 tons. Freshwater weight in freshwater systems with reverse osmosis of 15.56 tons.

From these calculations it can be compared that the fresh water weight of freshwater systems with the addition of reverse osmosis is eight times lighter than that of conventional fresh water systems. Here the weight of reverse osmosis system components :

TABLE 2.

DETAILS OF THE REVERSE OSMOSIS SYSTEM COMPONENT

\begin{tabular}{lccc}
\hline \multicolumn{1}{c}{ Components } & Units & \multicolumn{2}{c}{ Weight } \\
\hline Clarifier pump *) & 2 (SW pump) & 0 & $\mathrm{~kg}$ \\
\hline Raw water tank $*)$ & 1 (SW hydrophore) & 0 & $\mathrm{~kg}$ \\
\hline KMnO4 Tank & 1 & 50 & $\mathrm{~kg}$ \\
\hline Reactor tank & 1 & 100 & $\mathrm{~kg}$ \\
\hline Anti scalant tank & 1 & 50 & $\mathrm{~kg}$ \\
\hline Anti-fouling tank & 1 & 50 & $\mathrm{~kg}$ \\
\hline Pumps dosing chemicals & $3 @ 2,6 \mathrm{~kg}$ & 5,2 & $\mathrm{~kg}$ \\
\hline Catridge filter & $2 @ 5 \mathrm{~kg}$ & 10 & $\mathrm{~kg}$ \\
\hline Reverse Osmosis Unit & 1 & 363 & $\mathrm{~kg}$ \\
\hline Water tank products $*)$ & $2(\mathrm{FW} \mathrm{tank})$ & 0 & $\mathrm{~kg}$ \\
\hline Installation piping and fittings & & 100 & $\mathrm{~kg}$ \\
\hline Solar panels & $11 @ 18,5 \mathrm{~kg}$ & 203,5 & $\mathrm{~kg}$ \\
\hline Battery & $10 @ 75 \mathrm{~kg}$ & 750 & $\mathrm{~kg}$ \\
\hline Inverter & 1 & 14,8 & $\mathrm{~kg}$ \\
\hline Electrical installation & & 40 & $\mathrm{~kg}$ \\
\hline & Total weight & $1686,5 \mathrm{~kg}$ \\
\hline
\end{tabular}

The weight of these reverse osmosis components includes the weight of the machining installation $(\mathrm{Wm})$ so as to represent the weight of the fixed component (LWT). Thus the LWT weight of the freshwater system with the addition of the reverse osmosis system increased by $+1686,6 \mathrm{~kg}$ (1,687 tons) from the conventional system. The calculation of payload of freshwater system with reverse osmosis can be calculated as follows:

Displacement vessel of conventional FW system $=\Delta_{1}$

Displacement ship FW system with RO $=\Delta_{2}$

$$
\Delta_{1}=\Delta_{2}
$$$$
\mathrm{DWT}_{1}+\mathrm{LWT}_{1}=\mathrm{DWT}_{2}+\mathrm{LWT}_{2}
$$

$\left(\right.$ Payload $\left.+\mathrm{Wt}_{1}\right)+\mathrm{LWT}_{1}=\left(\right.$ Payload $\left.+\mathrm{Wt}_{2}\right)+\mathrm{LWT}_{2}$

$\left(\right.$ Payload $\left.+\mathrm{Wt}_{1}\right)+\mathrm{LWT}_{1}=\left(\right.$ Payload $\left.+\mathrm{Wt}_{2}\right)+\mathrm{LWT}_{2}$ $\left(420+\mathrm{Wt}_{1}\right)+\mathrm{LWT}_{1}=\left(\right.$ Payload $_{2}+\left(\mathrm{Wt}_{1}-\right.$ $124,44))+\left(\mathrm{LWT}_{1}+1,687\right)$

Payload $_{2}=420+124,44-1,687$

Payload $_{2}=543$ tons

From the calculation can be seen that on the construction of new vessels payload value of the ship if the fresh water system is given the addition of reverse osmosis system is greater than the value of payload on the system in the freshwater system
Conventional. The difference of the payload value is

$$
+123 \text { tons. }
$$

4. Power Consumption Self

The need for electric power to operate the ship's reverse osmosis system does not require the power consumption of the ship generator because the required power is supplied from solar panels and batteries. So as not to increase the load power and fuel generator ship.

5. Quality of Processed Water Consumption

The reverse osmosis semipermeble membrane is capable of filtering out to $99 \%$ inorganic minerals that are still dissolved in water that already looks clear. Although the reverse osmosis membrane has the ability to filter organic substances contained in raw water but not all organic substances are filtered by the membrane and the quality of the processed water still meets the standards of clean water so it has a very good quality and can be directly drunk without cooking .

The quality of salted / brackish processed products using reverse osmosis system will be shown in the following table 3 . 
TABLE 3.

QUALITY OF PROCESSED WATER REVERSE OSMOSIS SYSTEM

\begin{tabular}{lccccc}
\hline Parameter & Units & $\begin{array}{c}\text { Raw } \\
\text { Water }\end{array}$ & $\begin{array}{c}\text { Standard of } \\
\text { Clean Water }\end{array}$ & $\begin{array}{c}\text { Water } \\
\text { Pretreatment }\end{array}$ & $\begin{array}{c}\text { Processed } \\
\text { Water RO }\end{array}$ \\
\hline Color & $\mathrm{TCU}$ & 111 & 50 & 14 & 10 \\
\hline TDS & $\mathrm{mg} / \mathrm{l}$ & 4420 & 1500 & 4100 & 140 \\
\hline $\begin{array}{l}\text { Organic } \\
\text { Substances } \\
\text { (KmnO4) }\end{array}$ & $\mathrm{mg} / \mathrm{l}$ & 59,57 & 10 & 11,4 & 3,48 \\
\hline Chloride & $\mathrm{mg} / \mathrm{l}$ & 2836,45 & 600 & 2770 & 61,06 \\
\hline
\end{tabular}

J. Economical Analysis of Conventional Freshwater Systems

The economic calculations of these systems are based on the price of each component and also the length of time of operation of each component (lifetime). To facilitate economic feasibility analysis. The cost of these costs will be grouped into

Some components. Where all these costs will be grouped into two, namely the cost of capital (capital cost) and the cost of the total amount of operation (annual cost).

1. Economical Analysis of Conventional FW System

The components to analyze economically the conventional fresh water system include the cost of capital, operating costs, operating time and freshwater prices. Calculation of components as follows :

Capital cost

- Age of project 20 Years

- Unexpected probability costs $10 \%$

- Engineering Cost 8\%

- Interest of $10 \%$

The capital cost of a conventional freshwater system is considered zero because in this system it has not been given the addition of reverse osmosis components for the process of desalination of sea water into fresh water.

Operating costs

- Need for fresh water during sailing 140,000 liters.

- 9 days of shipping time.
- Docking (annual survey) 1 year interval.

Average time of one time docking 2 weeks (14 days). Assumed the ship stopped working (idle) 3 months per year. Ship operating time $=365$ - docking time - idle $=365-14-90=261$ days.

So the number of cruise ship (Trip) in a year

$=261 / 9=29$ times.

- The price of fresh water is Rp 12,000 per cubic meter.

- Age of project 20 years.

- Assume fresh water prices to rise 5\% annually

Example : Period

$=\mathrm{n}$

Operational cost

$=\mathrm{P}$

The price of fresh water $=\mathrm{Q}$

Freshwater needs $\quad=\mathrm{x}$

Operational costs for conventional freshwater systems are similar to those of fresh water during sail $\mathrm{x}$ freshwater prices.

Pn $=$ Qn.X

Where $\mathrm{x}=140 \mathrm{~m} 3$

For $\mathrm{n}=1 \rightarrow \mathrm{Q} 1=12,000$

$\mathrm{N}=2 \rightarrow \mathrm{Q} 2=5 \% \mathrm{Q} 1+\mathrm{Q} 1$

$\mathrm{N}=3 \rightarrow \mathrm{Q} 3=5 \% \mathrm{Q} 2+\mathrm{Q} 2$

$\mathrm{N}=20 \rightarrow \mathrm{Q} 20=5 \% \mathrm{Q} 19+\mathrm{Q} 19$

The following is the operational cost calculation for conventional fresh water systems. 
TABLE 4.

FRESHWATER COST CALCULATION

\begin{tabular}{cccc}
\hline $\begin{array}{c}\text { Period to } \\
(\mathrm{n})\end{array}$ & $\begin{array}{c}\text { Price FW/m } \\
\text { per year }\end{array}$ & $\begin{array}{c}\text { Cost FW }(\mathrm{Qn}) \\
(1 \text { x voyage })\end{array}$ & $\begin{array}{c}\text { Operational cost 1 year }(\mathrm{Pn}) \\
(29 \text { x voyage })\end{array}$ \\
\hline 1 & 12.000 & 1.680 .000 & 48.720 .000 \\
\hline 2 & 12.600 & 1.764 .000 & 51.156 .000 \\
\hline 3 & 13.230 & 1.852 .200 & 53.713 .800 \\
\hline 4 & 13.892 & 1.944 .880 & 56.401 .520 \\
\hline 5 & 14.582 & 2.041 .480 & 59.202 .920 \\
\hline 6 & 15.315 & 2.144 .100 & 62.178 .900 \\
\hline 7 & 16.081 & 2.251 .340 & 65.288 .860 \\
\hline 8 & 16.885 & 2.363 .900 & 68.553 .100 \\
\hline 9 & 17.729 & 2.482 .060 & 71.979 .740 \\
\hline 10 & 18.616 & 2.606 .240 & 75.580 .960 \\
\hline 11 & 19.547 & 2.736 .580 & 79.360 .820 \\
\hline 12 & 20.524 & 2.873 .360 & 83.327 .440 \\
\hline 13 & 21.550 & 3.017 .000 & 87.493 .000 \\
\hline 14 & 22.628 & 3.167 .920 & 91.869 .680 \\
\hline 15 & 23.759 & 3.326 .260 & 96.461 .540 \\
\hline 16 & 24.947 & 3.492 .580 & 101.284 .820 \\
\hline 17 & 26.194 & 3.667 .160 & 106.347 .640 \\
\hline 18 & 27.504 & 3.850 .560 & 111.666 .240 \\
\hline 19 & 28.879 & 4.043 .060 & 117.248 .740 \\
\hline 20 & 30.323 & 4.245 .220 & 123.111 .380 \\
\hline & Operational costs for 20 years & 1.610 .947 .100 \\
\hline
\end{tabular}

Operational costs for conventional fresh water systems always increase every year. This is because the price of fresh water also rises. This fresh water price increase is assumed to be 5\% annually. From these data shows the operational cost of conventional fresh water system for 20 years is Rp. 1.610.947.100.

The total cost of freshwater needs for 20 years equals the cost of capital + operating costs for 20 years. The total cost to meet the freshwater needs during the project life (20 years) is equal to the operational cost of the vessel because in the conventional system the capital cost is zero. Thus, the total cost of the conventional fresh water system MV.SABUK NUSANTARA 56 over the life of the project (20 years) is Rp. 1.610.947.100.

K. Economical Analysis of FW system with RO

The components for economically analyzing freshwater systems with the addition of reverse osmosis systems include cost of capital, operational cost, operating time and load value. Calculation of components as follows: 
TABLE 5 .

COST DETAILS OF REVERSE OSMOSIS SYSTEM COMPONENTS

\begin{tabular}{|c|c|c|c|c|}
\hline No & Components & Unit & Price/Unit & Price $(\mathrm{Rp})$ \\
\hline 1 & Piping installation and fitting & 1 & 3.000 .000 & 3.000 .000 \\
\hline 2 & Clarifier pump (SW pump) *) & 2 & & 0 \\
\hline 3 & Raw water tank $*)$ & 1 & & 0 \\
\hline 4 & Reactor tank & 1 & 7.500 .000 & 7.500 .000 \\
\hline 5 & Dosing pump 100/003 & 3 & 5.250 .000 & 5.250 .000 \\
\hline \multirow{3}{*}{6} & KMnO4 Tank & \multirow{3}{*}{3} & \multirow{3}{*}{3.250 .000} & \multirow{3}{*}{9.750 .000} \\
\hline & Anti scalant tank & & & \\
\hline & Anti-fouling tank & & & \\
\hline 7 & Catridge filter 5 micron & 2 & 1.750 .000 & 2.500 .000 \\
\hline \multirow{2}{*}{8} & Reverse osmosis unit & \multirow{2}{*}{ Package } & & \multirow{2}{*}{32.000 .000} \\
\hline & Crane Environmental Eliminator VI & & & \\
\hline 9 & Water tank products $*$ ) & & & 0 \\
\hline 10 & Water pump products $*$ ) & & & 0 \\
\hline 11 & Solar panels & 11 & 3.250 .000 & 35.750 .000 \\
\hline 12 & Solar Charge Control & 1 & 11.500 .000 & 34.500 .000 \\
\hline 13 & Battery & 10 & 29.300 .000 & 293.000 .000 \\
\hline 14 & Inverter & 1 & 25.500 .000 & 25.500 .000 \\
\hline \multirow[t]{2}{*}{15} & Electrical installation & & 4.000 .000 & 4.000 .000 \\
\hline & Total cost & & & 452.750 .000 \\
\hline
\end{tabular}

Capital cost

- Age of project 20 Years

- Unexpected probability costs $10 \%$

- Engineering Cost 8\%

- Interest of $10 \%$

Capital cost $=[\mathrm{A}]+[\mathrm{B}]+[\mathrm{C}]$

Where: $[\mathrm{A}]=$ Direct $\cos \mathrm{t}=\mathrm{Rp} 452.750 .000$

$[\mathrm{B}]=$ Unexpected cost $=10 \%$ direct cost

$=\operatorname{Rp} 45.275 .000$

$[\mathrm{C}]=$ Technical cost $=8 \%$ direct cost $=\operatorname{Rp} 36.220 .000$

So the cost of capital is as follows:

Capital cost $=452.750 .000+45.275 .000+$

36.220 .000

$=\operatorname{Rp} 534.245 .000$

Operational costs in freshwater systems with the addition of reverse osmosis systems with power supplies from solar panels and batteries need not cost to buy fresh water from the port because with the addition of reverse osmosis systems, freshwater systems on board are able to produce their own freshwater by desalination process. So the cost for fresh water needs is considered zero.

Operational costs in the use of the reverse osmosis system include the replacement of spare parts which includes cartridge filters, filter media and also the replacement of osmotic membrane elements in the reverse osmosis unit. To operate this unit also does not require fuel and lubricants due to the power supply needed in the supply by the panel Solar and batteries. Thus, the operational costs for the operation of the reverse osmosis system on the MV.SABUK NUSANTARA 56 ships only include the replacement of spart parts, the addition of reverse osmosis chemicals and the replacement of the batteries. Here are the details of the cost of replacement of spare parts, the addition of reverse osmosis chemicals and battery replacement. 
International Journal of Marine Engineering Innovation and Research, Vol. 1(4), Sept. 2017. 330-345 (pISSN: 2541-5972, eISSN:2548-1479)

TABLE 6.

DETAILS OF REVERSE OSMOSIS REVERSAL COST

\begin{tabular}{|c|c|c|c|c|}
\hline No & Description & Lifetime & Total price & Grand total \\
\hline \multirow[t]{6}{*}{1} & Spare part & & & \\
\hline & Filter catridge & 6-9 month & 700.000 & 1.050 .000 \\
\hline & Media filter: & & & \\
\hline & Activated carbon filter & 6-12 month & 600.000 & 900.000 \\
\hline & Membrane RO & 3-5 years & 3.600 .000 & 3.600 .000 \\
\hline & other things & 1 year & & 1.200 .000 \\
\hline \multirow[t]{4}{*}{2} & Chemical material & & & \\
\hline & KMnO4 solution & 1 year & 320.000 & 320.000 \\
\hline & Antiscalant solution & 1 year & 320.000 & 320.000 \\
\hline & Anti-fouling solution & 1 year & 320.000 & 320.000 \\
\hline 3 & Battery & 10 years & 293.000 .000 & 29.300 .000 \\
\hline \multicolumn{4}{|c|}{ Total cost per year } & 57.970 .000 \\
\hline
\end{tabular}

- Lifetime of project 20 Years

- Assume the cost of spare parts and chemicals up $5 \%$ annually

Example:

Period $=\mathrm{n}$

Operational cost $=\mathrm{P}$

Cost of spare part $/$ year $=\mathrm{Y}$

Chemical cost $/$ year $=\mathrm{Z}$

$$
\begin{aligned}
& \mathrm{Pn}=\mathrm{Yn}+\mathrm{Zn} \\
& \text { For } \mathrm{n}=1 \rightarrow \mathrm{Y} 1=57.010 .000 ; \mathrm{Z} 1=960.000 \\
& \text { For } \mathrm{n}=2 \rightarrow \mathrm{Y} 2=5 \% \mathrm{Y} 1+\mathrm{Y} 1 ; \mathrm{Z} 2=5 \% \mathrm{Z} 1+\mathrm{Z} 1 \\
& \text { For } n=3 \rightarrow Y 3=5 \% \text { Y } 2+Y 2 ; Z 3=5 \% Z 2+Z 2 \\
& \text { For } \mathrm{n}=20 \rightarrow \mathrm{Y} 20=5 \% \mathrm{Y} 19+\mathrm{Y} 19 ; \mathrm{Z} 20=5 \% \\
& \mathrm{Z} 19+\mathrm{Z} 19
\end{aligned}
$$

Operational cost to operate the reverse osmosis unit per year $=$ spare part cost $/$ year + chemical cost $/$ year

TABLE 7.

OPERATIONAL COST CALCULATION OF REVERSE OSMOSIS SYSTEM

\begin{tabular}{cccr}
\hline $\begin{array}{c}\text { Period to } \\
(\mathrm{n})\end{array}$ & $\begin{array}{c}\text { Spare part cost }(\mathrm{Y}) \\
\text { Per year }\end{array}$ & $\begin{array}{c}\text { Chemical cost }(\mathrm{Z}) \\
\text { Up 5\% / year }\end{array}$ & $\begin{array}{c}\text { Operational cost 1 year (Pn) } \\
(29 \text { x voyage) }\end{array}$ \\
\hline 1 & 57.010 .000 & 960.000 & 57.970 .000 \\
\hline 2 & 59.860 .500 & 1.008 .000 & 60.868 .500 \\
\hline 3 & 62.853 .525 & 1.058 .400 & 63.911 .925 \\
\hline 4 & 65.996 .201 & 1.111 .320 & 67.107 .521 \\
\hline 5 & 69.296 .011 & 1.166 .886 & 70.462 .897 \\
\hline 6 & 72.760 .812 & 1.225 .230 & 73.986 .042 \\
\hline 7 & 76.398 .852 & 1.286 .492 & 87.685 .344 \\
\hline 8 & 80.218 .795 & 1.350 .816 & 85.569 .612 \\
\hline 9 & 84.229 .735 & 1.418 .357 & 89.930 .497 \\
\hline 10 & 88.441 .222 & 1.489 .275 & 94.427 .022 \\
\hline 11 & 92.863 .283 & 1.563 .739 & 104.148 .373 \\
\hline 12 & 97.506 .447 & 1.641 .926 & 109.311 .081 \\
\hline 13 & 102.381 .769 & 1.724 .022 & 114.776 .635 \\
\hline 14 & 107.500 .858 & 1.810 .223 & 120.515 .467 \\
\hline 15 & 112.875 .900 & 1.900 .734 & 126.541 .240 \\
\hline 16 & 118.519 .696 & 1.995 .771 & 132.868 .302 \\
\hline 17 & 124.445 .680 & 2.095 .560 & 139.511 .717 \\
\hline 18 & 130.667 .964 & 2.200 .338 & 146.487 .303 \\
\hline 19 & 137.201 .363 & 2.310 .354 & 1.916 .833 .359 \\
\hline 20 & 144.061 .431 & 2.425 .872 &
\end{tabular}

Operational cost of freshwater system with reverse osmosis system always increase every year. This is because the price of spare parts and chemicals also increase. The price increase is assumed to be $5 \%$ per year. From the calculation data shows the operational cost of freshwater system with reverse osmosis system for 20 years is Rp. 1.916.833.359.

The total cost of freshwater needs for 20 years is as follows: Capital cost + operating expenses for 20 years 
TABLE 8.

TOTAL OPERATING COST CALCULATION OF RO SySTEM

\begin{tabular}{|c|c|c|c|}
\hline Period to & Capital cost (investment) & Operational cost (Rp)/year & Total cost (Rp) \\
\hline 1 & 534.245 .000 & 57.970 .000 & 592.215 .000 \\
\hline 2 & & 60.868 .500 & 60.868 .500 \\
\hline 3 & & 63.911 .925 & 63.911 .925 \\
\hline 4 & & 67.107 .521 & 67.107 .521 \\
\hline 5 & & 70.462 .897 & 70.462 .897 \\
\hline 6 & & 73.986 .042 & 73.986 .042 \\
\hline 7 & & 77.685 .344 & 77.685 .344 \\
\hline 8 & & 81.569 .612 & 81.569 .612 \\
\hline 9 & & 85.648 .092 & 85.648 .092 \\
\hline 10 & & 89.930 .497 & 89.930 .497 \\
\hline 11 & & 94.427 .022 & 94.427 .022 \\
\hline 12 & & 99.148 .373 & 99.148 .373 \\
\hline 13 & & 104.105 .791 & 104.105.791 \\
\hline 14 & & 109.311 .081 & 109.311 .081 \\
\hline 15 & & 114.776 .635 & 114.776 .635 \\
\hline 16 & & 120.515 .467 & 120.515 .467 \\
\hline 17 & & 126.541 .240 & 126.541 .240 \\
\hline 18 & & 132.868 .302 & 132.868 .302 \\
\hline 19 & & 139.511 .717 & 139.511 .717 \\
\hline 20 & & 146.487 .303 & 146.487 .303 \\
\hline
\end{tabular}

The total cost to meet the freshwater needs during the project life (20 years) is the operational cost over the life of the project plus the cost of capital expended. The capital cost of the freshwater system with reverse osmosis is Rp. 534.245.000 and the operational cost is Rp. 1.916.833.359.
Thus, the total cost of the freshwater system with the addition of the reverse osmosis system over the life of the project is Rp. 2.451.078.361

L. Comparison Graph of Total Cost of Conventional FW System With FW RO System

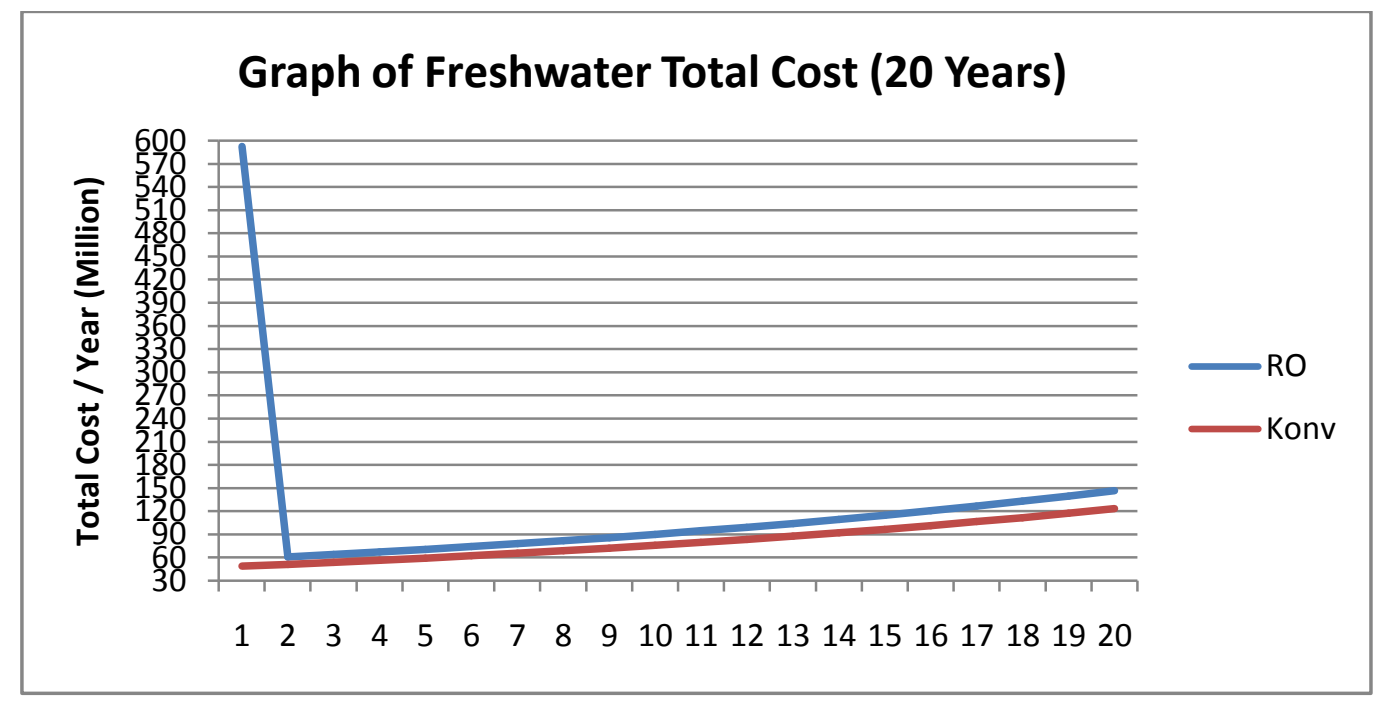

Figure. 7.Graph of Freshwater Total Cost (20 Years)

From the graph above it can be seen that in the 1st period the total cost of freshwater systems with reverse osmosis system is greater than the conventional system. This is because the freshwater system with the addition of the reverse osmosis system requires a relatively large capital cost for the procurement of the reverse osmosis unit and its supporting components. While the conventional system does not incur capital costs because the supply of fresh water is done by filling the freshwater tank from the ground. So the costs incurred are only the operational costs only. During the 2nd to the 20th period the total costs 
incurred in freshwater systems with reverse osmosis are smaller than those of conventional fresh water systems. The difference of the cost is an average of $10 \%$ per year. This is because the freshwater system with the reverse osmosis system must pay for replacement and replenishment of components from the fresh water system using the reverse osmosis system.

\section{Payload}

Based on the results of research in the form of data analysis and discussion obtained results as follows: - Judging from technical factorsThe advantages of fresh water system with reverse osmosis systeminclude:

- Ships capable of producing freshwater ready todrink 32712 LPD.

- Able to reduce the size of freshwater tank from 140 $\mathrm{m} 3$ to $16 \mathrm{~m} 3$.

- For the construction of new vessels able to increase the value of payload (payload) up to 123 tons.

- Power consumption of solar panels and batteries of $2.33 \mathrm{~kW}$

The disadvantages of freshwater systems with reverse osmosis systems are more complex and lengthy installations because feed water must be processed first to remove particulates and the power required for operations to be satisfied by a separate electrical system. In addition, this system also requires repair and maintenance periodically. - Viewed from economic factors

- The cost of capital for freshwater systems with reverse osmosis is more expensive than conventional systems of Rp. 534.245.000.

- The cost of operating a freshwater system with reverse osmosis is more expensive than the conventional system with an average of $10 \%$ annually.

- The total cost over the life of the freshwater system project with reverse osmosis is more expensive than the conventional fresh water system of $\mathrm{Rp}$. 840.131 .261

- The total cost of freshwater systems with reverse osmosis systems is cheaper \pm 52 percent of the total cost of conventional fresh water systems.

- The ship's payload (Payload) increases by Rp. 1.107 million.

- The payload value that the ship will carry if the freshwater system is added to the reverse osmosis system is greater than \pm 29.2 percent of the conventional carrying capacity of the ship carrying the vessel on a conventional fresh water system.

From the analysis and discussion technically and economically it can be concluded that with the many advantages of the reverse osmosis system with the power supply of solar panels and batteries reverse osmosis system is very appropriate when applied to ships and boats ro-pax with the level of need Highfresh water and also a relatively remote shipping route.

\section{B. Suggestions}

Based on the results of the analysis and conclusions obtained then there are some things that require effort in order to get maximum results and efficient. This final project is not perfect, therefore requires supportive suggestions to create maximum and accurate results for the upcoming task. The suggestions for this final project are:

- Data for the design of freshwater systems and supporting documents is minimal and insufficient detail.

- The results of technical analysis do not discuss the operational efficiency of the reverse osmosis system with the supply of solar and battery power.

- Do not do the simulation so it can know the time required for solar thermal conversion into electricity. - Economic analysis is still an estimate.

\section{REFFERENCES}

[1]Handayani, Nadia. 2014 Analisa Kinerja Termal Solar Apparatus Panel pada Alat Destilasi Air Payau dengan Sistem Evaporasi Uap Tenaga Matahari Menggunakan CFD. ITS. Surabaya.

[2]World Health Organization and UNICEF, Meeting the MDGdrinking water and sanitation target, 2006,http://www.whoint/water_sanitation_health/monitoring/jm pfinal.pdf, accessed July 12, 2017.

[3] Bilton, Amy M, Leah C Kelly, Steven Dubowsky. 2011. Photovoltaic Reverse Osmosis Feasibility And A Pathway To Develop Technology. Massachusetts Institute of Technology. Cambridge. USA.

[4] Suryadi.2011. Analisa Teknis Ekonomis Perencanaan Sistem Reverse Osmosis Untuk Kebutuhan Air Tawar Domestic Fresh Water System Pada Kapal Niaga MV. AVILA. ITS. Surabaya.

[5] Hakim, Fahmi Muhammad. 2017. Perancangan Rooftop Off Grid Solar Panel Pada Rumah Tinggal Sebagai Alternatif Sumber Energi Listrik, Polinema, Malang.

[6] A. Baheramsyah, B. Cahyono, and F. S. Aruan, "Slurry Ice as a Cooling System on 30 GT Fishing Vessel," International Journal of Marine Engineering Innovation and Research., vol. 1, no. 3, Jun. 2017.

[7] H. Prastowo, D. P. Widodo, Semin, and W. Rohmawati, "Technical Analysis Ballast Water Treatment By Using Economizer Utilizing Main Engines Exhaust Heat To Comply With International Ship Ballast Water Management At Mv. Leader Win," International Journal of Marine Engineering Innovation and Research., vol. 1, no. 2, Mar. 2017.

[8] A. Z. M. Fathallah, W. Busse, and F. R. Clausthaldi, "Fluid Flow Analysis of Jacket Cooling System for Marine Diesel Engine $93 \mathrm{Kw}$," International Journal of Marine Engineering Innovation and Research., vol. 1, no. 2, Mar. 2017. 